\title{
Enhancement of Bacteriophage $\phi$ X-174 Plaques by Homoionic Clay Minerals
}

\author{
By STEVEN M. LIPSON ${ }^{1,2 *}$ AND OSAMA A. ALSMADI ${ }^{2}$ \\ ${ }^{1}$ Virology Laboratory, Nassau County Medical Center, East Meadow, New York 11554, USA \\ ${ }^{2}$ Department of Health Sciences, C. W. Post College, Long Island University, Greenvale, \\ New York, USA
}

(Received 10 February 1989; revised 5 June 1989; accepted 4 September 1989)

\begin{abstract}
The incorporation of selected particulates or charged polymers into qualitative and quantitative assay systems has been found to increase virus specific infectivity. The purpose of this study was to identify a mechanism(s) to explain the effect of charged particulates upon plaquing efficiency. The clay minerals kaolinite $(\mathrm{K})$, montmorillonite $(\mathrm{M})$, with the bacteriophage $\phi \mathrm{X}-174$ and its host Escherichia coli, were used as a model system. Enhanced bacteriophage infectivity (expressed as plaque-forming units) occurred at $\mathbf{K}$ and $\mathbf{M}$ concentrations in the agar overlay of $0 \cdot 14-0.50$ and $0 \cdot 01-0.15 \mathrm{mg} \mathrm{ml}^{-1}$, respectively. A maximum increase of bacteriophage titre (to $180-230 \%$ of the control value) occurred at $0.18-0.20$ and $0.06-0.08 \mathrm{mg} \mathrm{ml}^{-1} \mathrm{~K}$ and $\mathbf{M}$, respectively. Increased infectivity was related to the type of clay mineral and to the cation saturating the exchange complex in the order $\mathrm{K}$ homoionic (i.e. saturated with a single cation type) to $\mathrm{Na}^{+}>\mathrm{Mg}^{2+}>\mathrm{K}^{+}$and $\mathrm{M}$ homoionic to $\mathrm{Mg}^{2+}>\mathrm{Na}^{+}>\mathrm{K}^{+}$. Enhanced infectivity of the bacteriophage was not related to the surface area of $K$ nor to the external or total surface area of M. The increase of bacteriophage titre above that of the control was only minimally related to cation-exchange capacity, but was associated with the anion-exchange capacity of the clay. The increased plaquing efficiency is ascribed to the formation of high-density bacteria-clay microcosms which, in turn, modify bacteriophage contact and adsorption to the host cell.
\end{abstract}

\section{INTRODUCTION}

The incorporation of particles with a net negative charge (e.g. montmorillonite) and certain cationic and anionic polymers into overlay (liquid) medium has been found to increase virus infectivity more than threefold. Similar effects brought about by the incorporation of charged particles and polymers have also been observed with various non-related virus groups in qualitative assay systems (Bishai \& Labzoffsky, 1974; Craighead \& Lane, 1969; Kaplan et al., 1967; Lipson \& Stotzky, 1985; Nguyen et al., 1987; Shirobokov, 1973; Takemoto \& Liebhaber, 1962; Wallis \& Melnick, 1968). The enhancement of virus infectivity by charged particles and molecular polymers has been ascribed to several mechanisms, including alteration of electrostatic forces at the virus-cell interface, increased diffusion efficiency through the overlay gel, the removal of inhibitors from the overlay medium, dispersive and carrier effects, abrasion of the host cell (in plant systems), and the inhibition of nucleases (Bishai \& Labzoffsky, 1974; Craighead \& Lane, 1969; Crandell \& Gomes, 1970; Dunn \& Hitchborne, 1965; Lipson \& Stotzky, 1987; Nguyen et al., 1987; Kaplan et al., 1967; Shirobokov, 1973; Takemoto \& Liebhaber, 1962; Toyoshima \& Vogt, 1969; Vaheri et al., 1967; Wallis \& Melnick, 1968; Yarwood, 1966, 1972).

\footnotetext{
* Address reprint requests to: S. M. Lipson, Virology Laboratory, Department of Pathology and Laboratories, Nassau County Medical Center, 2201 Hempstead Turnpike, East Meadow, New York 11554, USA.

Abbreviations: AEC, anion-exchange capacity; CEC, cation-exchange capacity; K, kaolinite; M, montmorillonite.
} 
Negatively-charged particles and cationic polymers in general increase virus infectivity. Polyanions, on the other hand, commonly suppress virus adsorption and growth. However, numerous exceptions, albeit ill-defined, have been reported (Craighead \& Lane, 1969; Nguyen et al., 1987; Takemoto \& Liebhaber, 1962; Toyoshima \& Vogt, 1969; Wiggins \& Alexander, 1985; Wunner et al., 1984). In an effort to investigate this phenomenon, a model system was constructed wherein the plaquing efficiency of the bacteriophage $\phi X-174$ was studied in the presence of two highly reactive aluminosilicate clay minerals, namely kaolinite and montmorillonite. The physicochemical characteristics of these clays are not only well defined, but they differ sufficiently to permit a clear analysis of those reactions which might occur at the bacteriophage-clay-cell interface.

\section{METHODS}

Bacteriophage and host cell. Bacteriophage $\phi \mathrm{X}-174$ and its host, Escherichia coli $\mathrm{C}$, were purchased from Carolina Biological Supply Co. [cat. no. 12-4425 (ATCC no. 13706-B1, 1982) and 12-4400, respectively]. Bacteriophage stock was $6.7 \times 10^{8}$ plaque-forming units (p.f.u.) $\mathrm{ml}^{-1}$ in tryptone broth medium $(10 \mathrm{~g} \mathrm{Bacto-tryptone,} 5 \mathrm{~g} \mathrm{KCl}$, $2 \mathrm{ml} 1 \mathrm{M}-\mathrm{CaCl}_{2} \mathrm{1}^{-1}$ ). The stock was diluted in sterile distilled $\mathrm{H}_{2} \mathrm{O}$ to obtain titres appropriate for the experiments. Preliminary experiments revealed that dilution of the bacteriophage in either $\mathrm{H}_{2} \mathrm{O}$ or saline $(0.9 \%)$ resulted in similar plaque counts.

Clay minerals. Colloidal kaolin (kaolinite; K) (cat. no. K-6, lot no. 734748) and bentonite (montmorillonite; M) (cat. no. B-235, lot no. 730257B) were purchased from Fisher Chemical Co.

Preparation of homoionic clays. Twelve grams of $\mathrm{K}$ or $\mathrm{M}$ was suspended in $400 \mathrm{ml} 0.2 \mathrm{M}-\mathrm{Na}_{2} \mathrm{CO}_{3}$, and stirred for $3 \mathrm{~h}$. The resultant mixture was allowed to settle overnight at $4^{\circ} \mathrm{C}$. The upper third of each suspension was collected by aspiration, followed by centrifugation at $10000 \mathrm{~g}$ for $10 \mathrm{~min}$ at $4^{\circ} \mathrm{C}$. Sediments were washed three times ( $20000 \mathrm{~g}$ for $10 \mathrm{~min}$ at $4^{\circ} \mathrm{C}$ ) with $0.5 \mathrm{M}-\mathrm{NaCl}, 0.5 \mathrm{M}-\mathrm{KCl}$ or $0.25 \mathrm{M}-\mathrm{MgCl}_{2}$. These clays, in turn, were washed seven times with distilled water $(20000 \mathrm{~g})$ to obtain a chloride-free system.

Titration of bacteriophage and experimental design. Bacteriophage $\phi \mathrm{X}-174$ was assayed by the double agar layer technique (Adams, 1959). Briefly, $0.1 \mathrm{ml}$ stock virus (diluted in sterile distilled $\mathrm{H}_{2} \mathrm{O}$ ) was inoculated into $4.5 \mathrm{ml}$ overlay medium, viz. a tryptic soy broth (Difco, cat. no. 49800B0, consisting of $17 \mathrm{~g}$ Bacto-Tryptone, $3 \mathrm{~g}$ Bacto-

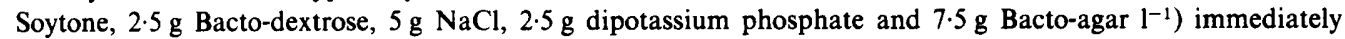
followed by seeding with $0.5 \mathrm{ml}$ exponential-phase bacterial host cells (about $10^{8}$ cells ml-1) and $0.1 \mathrm{ml}$ of each homoionic clay mineral to give final concentrations of $0.01,0.02,0.04,0.06,0.08,0 \cdot 10,0.15$ and $0.20 \mathrm{mg} \mathrm{M}$ or 0.14 , $0 \cdot 16,0 \cdot 18,0 \cdot 20,0 \cdot 22,0.50$ and $1.0 \mathrm{mg} \mathrm{K} \mathrm{ml}^{-1}$. The underlay consisted of tryptic soy broth, but containing $15 \mathrm{~g}$ agar $\mathrm{I}^{-1}$. Inoculated plates were permitted to gel at room temperature, then inverted and incubated at $37^{\circ} \mathrm{C}$ for $48 \mathrm{~h}$. Plaques were counted on an optical cell counter and are reported as p.f.u. per $0.1 \mathrm{ml}$. Controls, without the clay minerals, were run in parallel.

Statistics. Experiments were done in triplicate, and bacteriophage titrations were done at least in quadruplicate. The arithmetic mean \pm standard error of the mean (SEM) of control and experimental results were compared by Student's $t$-test. $P<0.05$ was taken to be statistically significant.

\section{RESULTS AND DISCUSSION}

Wherever surfaces occur, especially in the microenvironment, an opportunity for adsorption, either non-biological (e.g. due to hydrogen bonding, van der Waals forces) or biological (e.g. receptor site specificity) exists (Brock, 1966; Lipson \& Stotzky, 1987). The clay mineralbacteriophage assay system constructed in the current study typifies such an environment.

Within the range of $K$ and $M$ concentrations studied, enhanced infectivity of bacteriophage $\phi X-174$ occurred at $K$ and $M$ concentrations in the agar overlay of $0 \cdot 14-0.50$ and $0.01-2.0 \mathrm{mg}$ $\mathrm{ml}^{-1}$ (except $\mathrm{M}$ homoionic to $\mathrm{K}^{+}$ions), respectively (Fig. 1). The maximum increase in titre occurred at 0.18 and $0.20 \mathrm{mg} \mathrm{K} \mathrm{ml}^{-1}(180-210 \%)$, and at 0.06 and $0.08 \mathrm{mg} \mathrm{M} \mathrm{m}^{-1}(180-230 \%)$. The increased infectivity of the bacteriophage was related to the type of clay mineral and to the cation saturating the exchange complex in the order $\mathrm{K}$ homoionic to $\mathrm{Na}^{+}>\mathrm{Mg}^{2+}>\mathrm{K}^{+}$, and $\mathrm{M}$ homoionic to $\mathrm{Mg}^{2+}>\mathrm{Na}^{+}>\mathrm{K}^{+}$.

Infectivity of the bacteriophage in the presence of each homoionic clay was plotted as a function of the surface area of $\mathrm{K}\left(15 \mathrm{~m}^{2} \mathrm{~g}^{-1}\right)$ and the external $\left(82 \mathrm{~m}^{2} \mathrm{~g}^{-1}\right)$ and total $\left(750 \mathrm{~m}^{2} \mathrm{~g}^{-1}\right)$ surface area of M (Lipson \& Stotzky, 1983). Infectivity of the phage was not related to the surface area of either clay mineral (data not shown). 


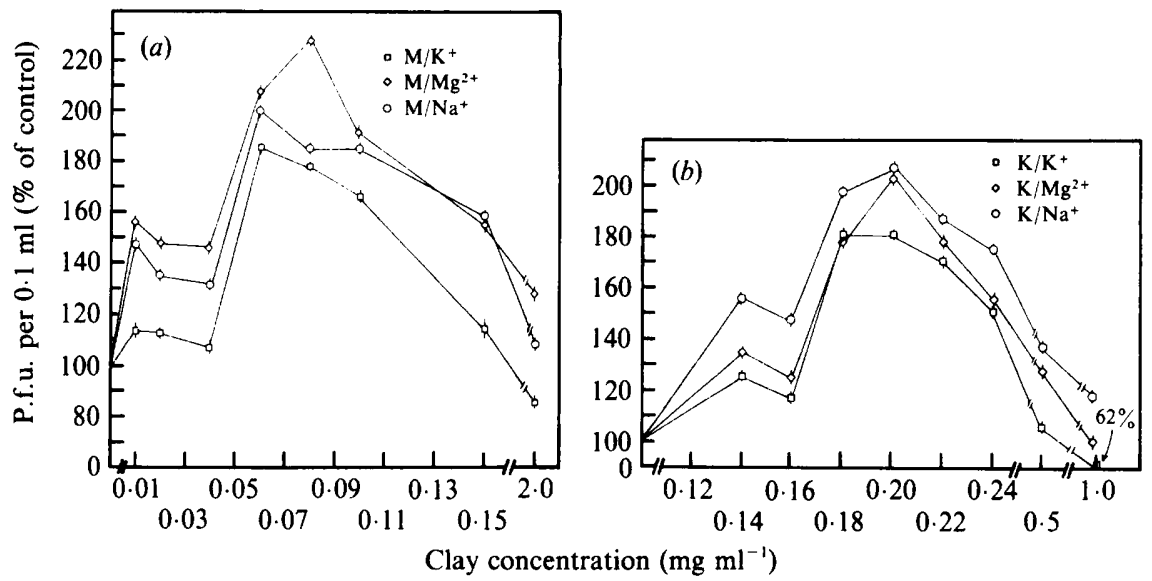

Fig. 1. Effect of clay minerals on the plaquing efficiency of bacteriophage $\phi X-174$. (a). Montmorillonite $(\mathrm{M})$ homoionic to potassium $\left(\mathrm{M} / \mathrm{K}^{+}\right)$, magnesium $\left(\mathrm{M} / \mathrm{Mg}^{2+}\right)$ and sodium $\left(\mathrm{M} / \mathrm{Na}^{+}\right)$. Bacteriophage added: $1.41 \pm 0.47 \times 10^{4}$ p.f.u. per $0.1 \mathrm{ml}$. (b) Kaolinite $(\mathrm{K})$ homoionic to potassium $\left(\mathrm{K} / \mathrm{K}^{+}\right)$, magnesium $\left(\mathrm{K} / \mathrm{Mg}^{2+}\right)$ and sodium $\left(\mathrm{K} / \mathrm{Na}^{+}\right)$. Bacteriophage added: $1 \cdot 30 \pm 0.53 \times 10^{4}$ p.f.u. per $0 \cdot 1 \mathrm{ml}$. The data are normalized on the basis of bacteriophage titres in the control (i.e. in the absence of either clay mineral), and are shown \pm SEM.

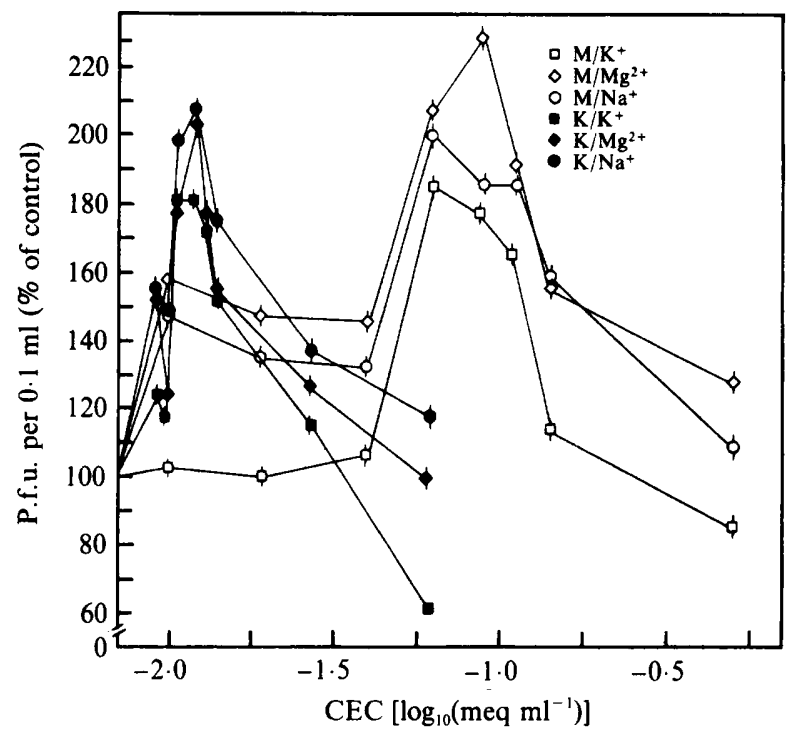

Fig. 2 Effect of CEC of $\mathrm{K}$ and $\mathrm{M}$ on the plaquing efficiency of bacteriophage $\phi \mathrm{X}-174$. CEC of $\mathrm{M}, 97.7$ meq per $100 \mathrm{~g}$ clay; CEC of $\mathrm{K}, 5.8 \mathrm{meq}$ per $100 \mathrm{~g}$ clay. The results are shown $\pm \mathrm{SEM}$.

Infectivity was further investigated as a factor of each clay mineral's cation- and anionexchange capacities. Cation/anion-exchange capacity refers to the ability of a substrate, such as a clay mineral, to adsorb, retain, and then release the ions in question. Enhanced infectivity of bacteriophage $\phi \mathrm{X}-174$ was minimally associated with the cation-exchange capacity (CEC) of K and $M(C E C=5.8$ and 97.7 meq per $100 \mathrm{~g}$ clay, respectively: Chaikum et al., 1981; Grim, 1968): increased plaquing efficiency was observed at the upper and lower concentration range of the $\mathrm{K}$ and $\mathrm{M}$ utilized in this study (Fig. 2). The reported anion-exchange capacity (AEC) of $\mathrm{K}$ remains ill-defined; values obtained in different laboratories reflect different exchange capacities due to the assays being performed in aqueous and non-aqueous $(95 \%$ ethanol) 


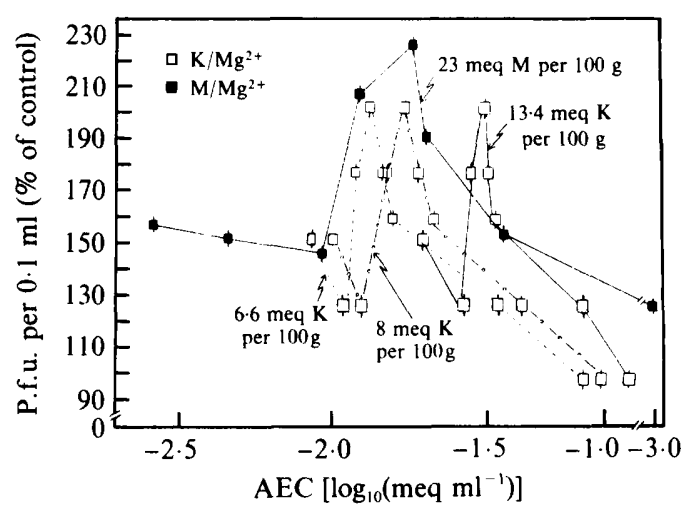

Fig. 3. Effect of $A E C$ of $K$ and $M$ on the plaquing efficiency of bacteriophage $\phi X-174$. AEC of $M, 23$ meq per $100 \mathrm{~g}$ clay; AEC of K, 6.6-13.4 meq per $100 \mathrm{~g}$ clay. The results are shown \pm SEM.

systems, and in varying electrolyte concentrations at different $\mathrm{pH}$ values. These factors, coupled with the exposure of $\mathrm{Al}^{3+}, \mathrm{Si}^{4+}$ or $\mathrm{Fe}^{3+}$ ions resulting from breakage at the edges of the clay, probably account for the reported large range of AEC values (from about 6.6 to 20 meq per $100 \mathrm{~g}$ clay: Ferris \& Jepson, 1975; Lipson \& Stotzky, 1987). Under controlled conditions, however, the AEC of K was found to be markedly reduced at neutral pH (Ferris \& Jepson, 1975). Such neutral conditions prevailed in the $\phi \mathrm{X}-174$ plaque assay utilized in the current study. Consequently, $\phi \mathrm{X}-$ 174 plaquing efficiency was plotted as a function of the lower $\mathrm{AEC}$ range of $\mathrm{K}$, and compared with the AEC value commonly recognized for the homoionic $M$ (i.e. $23 \mathrm{meq}$ per $100 \mathrm{~g}$ clay) (Grim, 1968). Our data show a strong association between increased bacteriophage plaquing efficiency and the AEC of the clays tested (Fig. 3).

Sorptive interactions between bacterial cells (Marshall, 1968, 1969a,b; Santoro \& Stotzky, $1967 a, 1968$ ), the tail-less bacteriophages (i.e. f2, $\phi \mathrm{X}-174)$ (Burge \& Enkiri, 1978; Goyal \& Gerba, 1979; Moore et al., 1975; Schaub et al., 1980), clay minerals and soil systems have been studied extensively. These investigations, as relevant to our study, indicate that bacterial cells adsorb primarily to positively-charged or anion-exchange sites on clay minerals. Adsorption of the tail-less phages at neutral $\mathrm{pH}$ by kaolinite, montmorillonite, sewage-containing water and numerous soil types also occurred, but at reduced levels (Boyce et al., 1981; Burge \& Enkiri, 1978; Drewry \& Eliassen, 1968; Koya \& Chaudhuri, 1977; Moore et al., 1975). A recent report by Armon \& Cabelli (1988), for example, confirmed that adsorption of tail-less baceriophages (i.e. $\mathrm{f}$ ) by $\mathrm{K}$ and $\mathrm{M}$ (homoionic to $\mathrm{Na}^{+}$ions) was minimal at the effective clay concentrations $\left(0 \cdot 18-0.20\right.$ and $0.06-0.08 \mathrm{mg} \mathrm{ml}^{-1}$, respectively) utilized in the current investigation. Goyal et al. (1980) reported a unique behavioural characteristic of the bacteriophage $\phi X-174$. Adsorption of the baceriophage suspended in secondary sewage, reservoir or bayou waters (at neutral $\mathrm{pH}$ ) to a Series S Zeta Plus filter was significantly reduced compared with that of phage types MS-2, T2 or T4.

These earlier findings, in conjunction with our data (Figs 2 and 3), suggest the following mechanism to account for the plaque-enhancement effect in this system. A preferential adsorption of $E$. coli, but not bacteriophage $\phi \mathrm{X}-174$, by $\mathrm{K}$ or $\mathrm{M}$ occurred in the overlay medium of the phage assay system, resulting in an increase in cell density on the clay surface and thereby creating localized high density bacteria-clay mineral microcosms. This enabled more efficient contact between the bacteriophage and its host cell. An apparent preferential adsorption by $\mathbf{M}$ of $E$. coli rather than bacteriophage T4 or M13 has been reported (Roper \& Marshall, 1974, $1978 a$; Wiggins \& Alexander, 1985). Significantly, the reported preferential adsorption of $E$. coli by M (Roper \& Marshall, 1974) occurred at low $\left(0.15 \mathrm{mg} \mathrm{ml}^{-1}\right)$ clay concentrations. The clay concentrations utilized by Roper \& Marshall (1974) were similar to those used in the current study. 


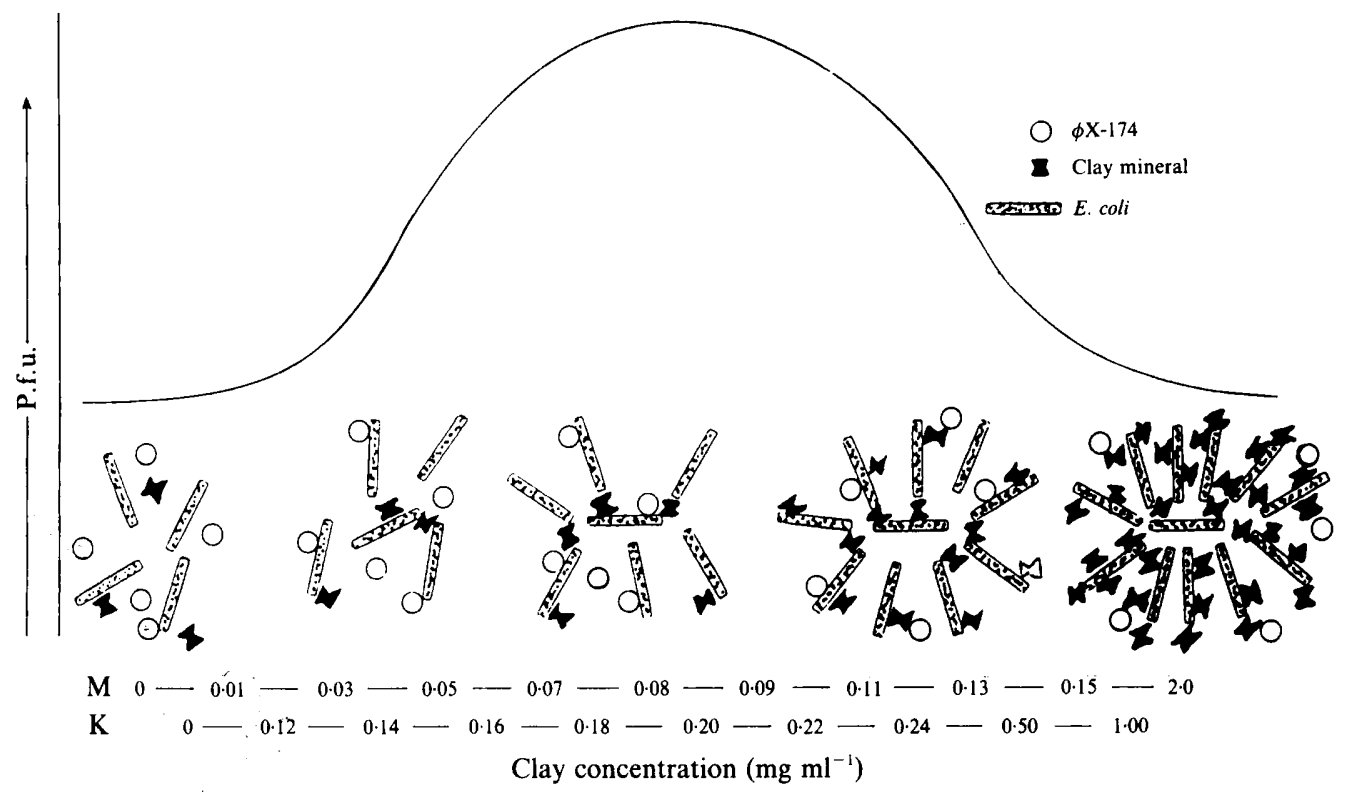

Fig. 4. Diagrammatic representation of the mechanism involved in the plaque enhancement effect of bacteriophage $\phi \times-174$ by $\mathrm{K}$ and $\mathrm{M}$. Addition of appropriate concentrations of $\mathrm{K}$ (about $0 \cdot 18-$ $0.20 \mathrm{mg} \mathrm{ml}^{-1}$ ) and $\mathrm{M}$ (about $0.06-0 \cdot 10 \mathrm{mg} \mathrm{ml}^{-1}$ ) to the overlay enhances the plaquing efficiency of $\phi \mathrm{X}$ 174 by producing high-density bacterial-clay mineral microenvironments. These aggregates of microbial cells in turn permit a more efficient contact (and adsorption) of the phage to its host cell. High clay concentrations physically block attachment of the phage to its host cell and thus reduce plaquing efficiency.

Higher clay concentrations (more than $0.50 \mathrm{mg} \mathrm{K} \mathrm{ml}^{-1}$ or $0.15 \mathrm{mg} \mathrm{M} \mathrm{ml}^{-1}$ ) reduced plaquing efficiency in our study. This result may be ascribed to the formation of a clay envelope around the cell, thereby preventing contact between the bacteriophage and its host. Similar protective effects of $E$. coli by $\mathbf{M}$ from phage attack and, to a lesser extent, from microbial predation, have been reported (Roper \& Marshall, 1974, 1978b). In a similar study, bacterial growth and, in turn, phage T4 production, may have been inhibited by the addition of a high concentration ( $5 \mathrm{mg} \mathrm{ml}^{-1}$ ) of $\mathrm{M}$ (Wiggins \& Alexander, 1985). However, the mechanism of cell or phage growth inhibition by $\mathbf{M}$ is difficult to explain, as suboptimal bacterial inocula and a single clay concentration were utilized by Wiggins \& Alexander (1985). Low K or M concentrations (i.e. trace or microgram levels) would have been expected to have no effect on phage plaquing efficiency, as clay- $E$. coli aggregates would not occur. A diagrammatic representation of our proposed mechanism is presented in Fig. 4.

An association between plaquing efficiency and a clay-bacteriophage sorptive reaction is also suggested by the differential effects on infectivity among the homoionic clays tested (i.e. $\mathrm{K}$ homoionic to $\mathrm{Na}^{+}>\mathrm{Mg}^{2+}>\mathrm{K}^{+}$and $\mathrm{M}$ homoionic to $\mathrm{Mg}^{2+}>\mathrm{Na}^{+}>\mathrm{K}^{+}$) (Fig. 1). Differences in plaquing efficiency relative to the type of cation saturating the exchange complex are consistent with the differences observed in the adsorption of reovirus type 3 and actinophage 6 to $\mathrm{K}$ and $\mathrm{M}$ or to $\mathrm{K}$ alone, respectively (Lipson \& Stotzky, 1983; Sykes \& Williams, 1978). It would not be unreasonable to suggest that $\mathrm{K}$ and $\mathrm{M}$ served, in part, as carrier vehicles of the phage to its host (Lipson \& Stotzky, 1985). It should be pointed out that the cation-exchange reactions referred to in the current study did not occur or occurred only minimally at the claybacterial cell interface, as adsorption of bacterial cells to clay minerals occurs primarily at anionexchange sites of inorganic colloids (Marshall, 1975). Factors responsible for the differential adsorption of viruses to homoionic clays have been previously described in detail (Lipson \& Stotzky, 1987). 
Removal of bacterial metabolites from the agar overlay by $K$ or $M$ is unlikely as an explanation of the results. In general, adsorption of microbial metabolites by clays appears to be related to the valency of the cation saturating the clay complex (i.e. tetravalent $>$ trivalent $>$ divalent) (Santoro \& Stotzky, 1967b). Our data, in contrast, show that plaque enhancement is associated with the AEC of the clays.

The effects of polymers or particulates on infectivity cannot be inferred from their electric charge alone. Differences between virus groups, types, strains within the same type, the host cell and the size of the charged agent itself, must be addressed prior to the utilization of an extrinsic substance to enhance infectivity (Craighead \& Lane, 1969; Crandell \& Gomes, 1970; Lipson \& Stotzky, 1984, 1985; Nguyen et al., 1987; Shirobokov, 1968; Takemoto \& Liebhaber, 1962; Toyoshima \& Vogt, 1969; Wallis \& Melnick, 1965; WuDunn \& Spear, 1989). In the current study, for example, one may not discount those unique physicochemical characteristics of $K$ and $M$ and, in turn, the differential enhancement effects of these clays on the plaquing efficiency of bacteriophage $\phi X-174$ (Fig. 4).

In summary, the incorporation of $\mathbf{K}$ or $\mathbf{M}$ into the overlay during the titration of bacteriophage $\phi X-174$ resulted in an increase in the number of plaques to some $180-230 \%$ of the control value. In our system, this effect was probably due to the formation of localized highdensity bacteria-clay mineral microcosms which, in turn, permitted an increased contact of the bacteriophage with its host cell. Some adsorption of the phage to cation-exchange sites on the clay mineral surface may have occurred as well, resulting in a transport (and enhanced contact) of the virion to its host cell. The results of this study suggest that the addition of clay minerals to other bacteriophage assay systems, or the use of these specific clays in the clinical setting (i.e. addition of $\mathbf{K}$ or $\mathbf{M}$ into maintenance medium), may be advantageous for the detection of viral titres below minimal levels capable of producing plaques or cytopathic effects.

This work was supported, in part, by grants from the Meadowbrook Medical, Education, and Research Foundation, Inc., and from Hoffman-La Roche Inc. The authors are grateful to H. P. Lipson for proof-reading the manuscript.

\section{REFERENCES}

ADAMS, A. M. (1959). Methods of study of bacterial viruses. In The Bacteriophages, pp. 443-457. Edited by A. M. Adams. New York: Wiley.

Armon, R. \& Cabelli, V. J. (1988). Phage f2 desorption from clays in estuarine water using nonionic detergents, beef extract, and chaotropic agents. Canadian Journal of Microbiology 34, 10221024.

Bishai, F. R. \& LABZOFFSKY, N. A. (1974). Stability of different viruses in a newly developed transport medium. Canadian Journal of Microbiology 20, 75-81.

Boyce, D. S., Sproul, O. J. \& Buck, C. E. (1981). The effect of bentonite clay on ozone disinfection of bacteria and viruses in water. Water Research 15 , 759-767.

Brock, T. D. (1966). Microbial Ecology, pp. 16-22. Englewood Cliffs, NJ: Prentice-Hall.

BURGE, W. D. \& ENkIRI, N. K. (1978). Virus adsorption by five soils. Journal of Environmental Quality 7, 73-76.

Chaikum, N., SooppipatT, N. \& Carr, R. M. (1981). The cation exchange capacity of some kaolin minerals. Journal of the Science Society of Thailand 7, 100-109.

Craighead, J. E. \& Lane, C. H. (1969). Contrasting effects of polycations of plaquing efficiency of encephalomyocarditis virus variants. Journal of Virology 3, 45-51.

Crandell, R. A. \& Gomes, I. (1970). Plaque morpho- logy of some South American strains of foot-andmouth disease virus and the effect of polyionic compounds on plaque formation. Archiv für die gesamte Virusforschung 30, 137-146.

Drewry, W. A. \& Eliassen, R. E. (1968). Virus movement in groundwater. Journal of the Water Pollution Control Federation 40, 257-271.

DunN, D. B. \& HitchBorNE, J. H. (1965). The use of bentonite in the purification of plant viruses. Virology 25, 171-192.

FERris, A. P. \& JePSON, W. B. (1975). The exchange capacities of kaolinite and the preparation of homoionic clays. Journal of Colloid and Interface Science 51, 245-259.

Goyal, S. M. \& Gerba, C. P. (1979). Comparative adsorption of human enteroviruses, simian rotavirus and selected bacteriophages to soils. Applied and Environmental Microbiology 38, 241-247.

Goyal, S. M., Zerda, K. S. \& Gerba, C. P. (1980). Concentration of coliphages from large volumes of water and wastewater. Applied and Environmental Microbiology 39, 85-91.

GrIM, R. E. (1968). Clay Mineralogy, 2nd edn, pp. 189, 226. New York: McGraw-Hill.

Kaplan, M. M., KikToR, T. J., MaEs, R. F., Camprell, J. B. \& Koprowski, H. (1967). Effect of polyions on the infectivity of rabies virus in tissue culture : construction of a single-cycle curve. Journal of Virology 1, 145-151. 
Koya, K. V. A. \& Chaudhuri, M. (1977). Virus retention by soil. Progress in Water Technology $\mathbf{9}$, 43-52.

Lipson, S. M. \& Stotzky, G. (1983). Adsorption of reovirus to clay minerals: effects of cation exchange capacity, cation saturation, and surface area. Applied and Environmental Microbiology 46, 673-682.

LIPSON, S. M. \& STOTZKy, G. (1984). Effect of proteins on reovirus adsorption to clay minerals. Applied and Environmental Microbiology 48, 525-530.

Lipson, S. M. \& Stotzky, G. (1985). Infectivity of reovirus adsorbed to homoionic and mixed-cation clays. Water Research 19, 227-234.

LIPSON, S. M. \& STOTZKY, G. (1987). Interactions between clay minerals and viruses. In Human Viruses in Sediments, Sludges, and Soils, pp. 187-230. Edited by V. C. Rao \& J. L. Melnick. Boca Raton, Florida: CRC Press.

MARSHALl, K. C. (1968). Interactions between colloidal montmorillonite and cells of Rhizobium species with different ionogenic surfaces. Biochimica et biophysica acta 156, 179-186.

MARShall, K. C. $(1969 a)$. Studies by microelectrophoresis and microscope techniques of the adsorption of illite and montmorillonite to rhizobia. Journal of General Microbiology 56, 301-306.

MARSHALL, K. C. (1969b). Orientation of clay particles on bacteria possessing different ionogenic surfaces. Biochimica et biophysica acta 193, 472-474.

MarShall, K. C. (1975). Clay mineralogy in relation to survival of soil bacteria. Annual Review of Phytopathology 13, 357-373.

Moore, B. E., SAGIK, B. P. \& Malina, J. F., JR (1975). Viral association with suspended solids. Water Research 9, 197-203.

Nguyen, T. D., Bottreau, E. \& Aynaud, J. M. (1987). Transmissible gastroenteritis (TGE) of swine: in vitro virus attachment and effects of polyanions and polycations. Veterinary Microbiology 14, 343-354.

Roper, M. M. \& Marshall, K. C. (1974). Modification of the interaction between Escherichia coli and bacteriophage in saline sediment. Microbial Ecology 1, 1-13.

ROPER, M. M. \& MARshall, K. C. (1978a). Effect of clay particle size on clay-Escherichia coli-bacteriophage interactions. Journal of General Microbiology 106, $187-189$.

ROPER, M. M. \& MARshall, K. C. (1978b). Effects of clay minerals on microbial predation and parasitism of Escherichia coli. Microbial Ecology 4, 279-289.

Santoro, T. \& StotzKy, G. (1967a). Effect of electrolyte composition and $\mathrm{pH}$ on the particle size distribution of microorganisms and clay minerals as determined by the electrical sensing zone method. Archives of Biochemistry and Biophysics 122, 664-669.

SANTORo, T. \& StotzKY, G. $(1967 b)$. Influence of cations on flocculation of clay minerals by microbial metabolites as determined by the electrical zone particle analyzer. Soil Science Society of America Proceedings 31, 761-765.

SANTORo, T. \& Stotzky, G. (1968). Sorption between microorganisms and clay minerals as determined by the electrical sensing zone particle analyzer. Canadian Journal of Microbiology 14, 299-309.

Schaub, S. A., Kenyon, K. F., Bledsoe, B. \& Thomas, R. E. (1980). Evaluation of the overland runoff mode of land wastewater treatment for virus removal. Applied and Environmental Microbiology 39, 127-134.

SHIRobokov, V. P. (1968). Differentiation of coxsackieviruses based on the character of adsorption onto bentonite. Acta virologica 12, 185.

SHIRoboKov, V. P. (1973). Use of bentonite overlay for titration of enteroviruses by the plaque method. Voprosy virusologii 18, 611-615.

SyKes, I. K. \& Williams, S. T. (1978). Interactions of actinophages and clays. Journal of General Microbiology 108, 97-102.

TAKEMOTO, K. K. \& LiebHABER, H. (1962). Viruspolysaccharide interactions. II. Enhancement of plaque formation and detection of variants of poliovirus with dextran sulfate. Virology 17, 499501.

Toyoshima, K. \& Vogt, P. K. (1969). Enhancement and inhibition of avian sarcoma virus by polycations and polyanions. Virology 38, 414-426.

Vaheri, A., Sedwick, W. D. \& Plotkin, S. A. (1967). Growth of rubella virus in BHK 21 cells. II. Enhancing effect of DEAE-dextran, semicarbazide and low doses of metabolic inhibitors. Proceedings of the Society for Experimental Biology and Medicine 125, 1092-1098.

Wallis, C. \& Melnick, J. L. (1965). Differences in cysteine dependence and chromatographic behavior between two type 4 echovirus strains. Journal of Bacteriology 89, 1310-1313.

Wallis, C. \& Melnick, J. L. (1968). Mechanism of enhancement of virus plaques by cationic polymers. Journal of Virology 2, 267-274.

Wiggins, B. A. \& AleXander, M. (1985). Minimum bacterial density for bacteriophage replication: implications for significance of bacteriophages in natural ecosystems. Applied and Environmental Microbiology 49, 19-23.

WuDUNN, D. \& SPEAR, P. C. (1989). Initial interaction of herpes simplex with cells is binding to heparin sulfate. Journal of Virology 63, 52-58.

WunNer, W. H., Reagan, K. J. \& Kaprowski, H. (1984). Characterization of saturable binding sites for rabies virus. Journal of Virology 50, 691-697.

YARWOOD, C. E. (1966). Bentonite aids virus transmission. Virology 28, 459-462.

YARWOOD, C. E. (1972). Virus transmission from Chenopodium amaranticolor. Plant Disease Reporter 56, 1085-1086. 